\title{
Cutaneous leiomyomas mimicking keloids
}

\section{Mięśniaki gładkokomórkowe skóry imitujące keloidy}

\author{
Dimitre Dimitrov', Radomir Reszke², Mowafak Mohamed Hamodat ${ }^{3}$, Jacek Szepietowski²
}

'PMW/SKMC Dermatology, Abu Dhabi, United Arab Emirates

2Department of Dermatology, Venereology and Allergology, Wrocław Medical University, Wroclaw, Poland

${ }^{3}$ Pathology and Laboratory Medicine, Sheikh Khalifa Medical City, Abu Dhabi, United Arab Emirates

Przegl Dermatol 2016, 103, 289-291

DOI: 10.5 | |4/dr.2016.61777

\section{KEY WORDS:}

differential diagnosis, keloid, cutaneous leiomyoma.

SŁOWA KLUCZOWE:

diagnostyka różnicowa, keloid, mięśniak gładkokomórkowy skóry.
ADDRESS FOR CORRESPONDENCE:

Prof. Jacek Szepietowski MD, PhD

Department of Dermatology,

Venereology and Allergology

Wrocław Medical University

1 Chalubinskiego St

50-368 Wrocław, Poland

phone: +48 601534853

e-mail: jacek.szepietowski@

umed.wroc.pl

\section{ABSTRACT}

Introduction. Cutaneous leiomyomas are rare, benign smooth muscle neoplasms of the skin. According to the origin of the tumor, there are three types of cutaneous leiomyomas: piloleiomyomas, angioleiomyomas and genital leiomyomas.

Objective. To present an uncommon case of cutaneous leiomyomas which, due to clinical similarities, had been previously misdiagnosed and managed as keloids.

Case report. A 23-year-old woman with Fitzpatrick skin type 4/5 was referred to the outpatient department of dermatology for treatment of keloids on the left shoulder. After examination we decided to take a skin biopsy for histopathological and immunohistochemical investigation, which revealed cutaneous leiomyomas.

Conclusions. Cutaneous leiomyomas may be misdiagnosed as keloids. The former are of clinical relevance as they may denote hereditary leiomyomatosis and renal cell cancer. Early recognition is of paramount importance and may be life-saving.

\section{STRESZCZENIE}

Wprowadzenie. Mięśniaki gładkokomórkowe skóry są rzadkimi guzami z mięśni gładkich. Wyróżnia się wśród nich trzy podtypy: piloleiomyoma, angioleiomyoma oraz mięśniaki okolicy płciowej.

Cel pracy. Przedstawienie nietypowego przypadku mięśniaków gładkokomórkowych skóry, które na podstawie obrazu klinicznego były wcześniej zdiagnozowane i leczone jak keloidy.

Opis przypadku. Kobieta 23-letnia z fototypem skóry 4/5 według Fitzpatricka została skierowana do poradni dermatologicznej w celu leczenia keloidów na lewym barku. Po badaniu klinicznym zdecydowano o wykonaniu biopsji skórnej w celu przeprowadzenia badania histopatologicznego oraz immunohistochemicznego, które wykazały obecność mięśniaków gładkokomórkowych skóry.

Wnioski. Mięśniaki gładkokomórkowe skóry mogą być błędnie zdiagnozowane jako keloidy. Guzy te mają znaczenie w praktyce klinicznej, ponieważ ich obecność może świadczyć o wrodzonej mięśniakowatości oraz raku nerkowokomórkowym. Wczesne ustalenie diagnozy jest szczególnie ważne i może uratować życie pacjenta. 


\section{INTRODUCTION}

Cutaneous leiomyomas are rare, benign smooth muscle neoplasms of the skin first described by Virchow in 1854 [1]. It is believed that most cutaneous leiomyomas originate from the arrector pili muscles, and these tumors are called piloleiomyomas [2]. Other cutaneous tumors with smooth muscle differentiation include angioleiomyomas (derived from smooth muscle of the blood vessel walls), and genital leiomyomas (derived from dartos muscle present in the scrotum, vulva, and nipple) [3].

Keloid is an abnormal proliferation of scar tissue that forms at the site of cutaneous injury, especially after surgical incision or trauma. It does not regress and grows beyond the original margins of the scar [4]. Keloids should not be confused with hypertrophic scars, which are raised scars that do not grow beyond the boundaries of the original wound and may diminish over time [5].

\section{OBJECTIVE}

We present an uncommon case of cutaneous leiomyomas which, due to clinical similarities, had

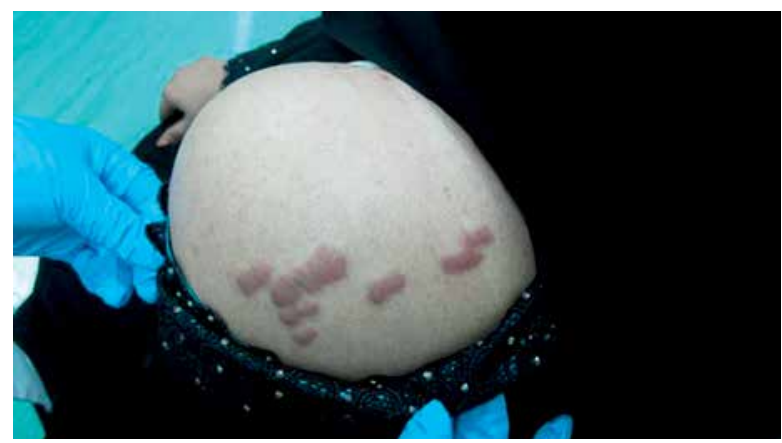

Figure I. Clinical presentation of the lesions located on the left shoulder

Rycina I. Obraz kliniczny zmian zlokalizowanych na lewym barku

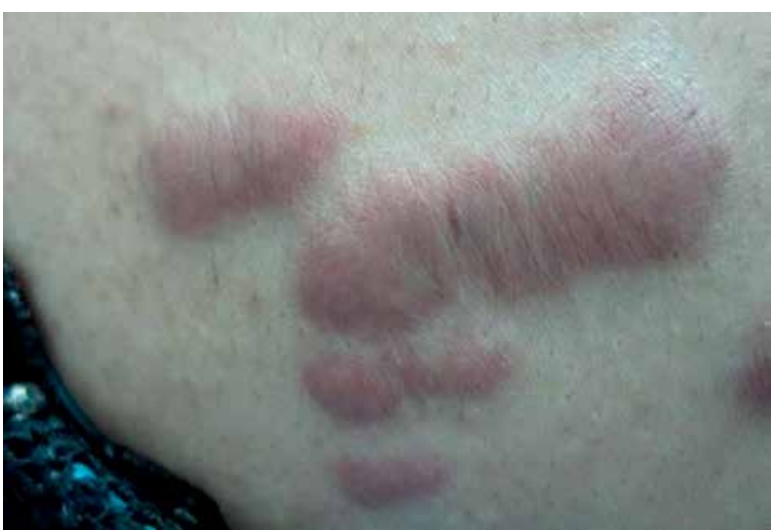

Figure 2. Upon closer examination, reddish-brown nodules with firm texture and smooth surface were visible

Rycina 2. Przy dokładniejszej analizie zmian zaobserwowano czerwonobrqzowe guzki o zwartej strukturze oraz gładkiej powierzchni been previously misdiagnosed and managed as keloids.

\section{CASE REPORT}

A 23-year-old woman with Fitzpatrick skin type $4 / 5$ was referred to the outpatient dermatological department for the treatment of keloids. The patient presented with multiple raised skin lesions on her left shoulder which had been present since childhood. She complained of mild to moderate itching and felt discomfort when the lesions were palpated. On examination, firm, dome-shaped, well-circumscribed, reddish-brown nodules, non-painful on palpation, were noted (Figs. 1, 2). The patient had no history of previous keloids or scars and no history of surgery or trauma. There were no other keloid- or scar-resembling lesions in other regions of skin. Moreover, there was no family history of similar or other cutaneous disorders. The patient had been diagnosed with diabetes mellitus since childhood. At the time of examination she was under treatment with insulin.

During history taking and physical examination a suspicion arose concerning the correctness of the diagnosis. Therefore, punch biopsy of the skin was performed with a $3 \mathrm{~mm}$ disposable punch and sent to the laboratory for histopathological and immunohistochemical evaluation. The biopsy revealed an ill-defined tumor within the reticular dermis, composed of broad interlacing fascicles of eosinophilic spindle cells (Fig. 3). Immunohistochemistry for smooth muscle actin was positive (Fig. 4), whereas stainings for S-100 and neurofilaments were negative. Based on the histopathological and immunohistochemical

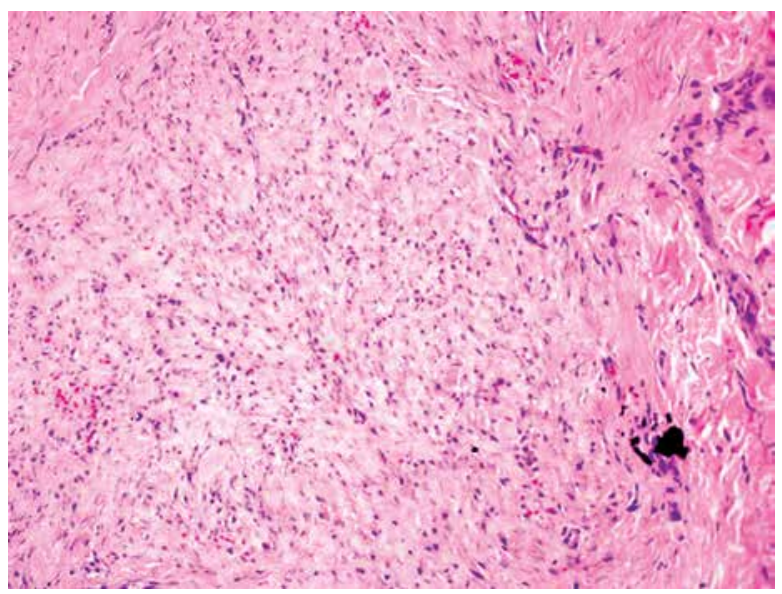

Figure 3. Section shows ill-defined tumor within the reticular dermis composed of broad interlacing fascicles of eosinophilic spindle cells ( $0 \times$ magnification; hematoxylin and eosin staining)

Rycina 3. W wycinku skórnym widoczne nieostro odgraniczone utkanie guza w obrębie warstwy siateczkowatej skóry właściwej składajace się z poszerzonych, przeplatajq̨cych się eozynochłonnych komórek wrzecionowatych (powiększenie I0x; barwienie hematoksyling i eozynq) 
observations the diagnosis of cutaneous leiomyomas was established. The patient was referred to the plastic surgery department. Total surgical excision of lesions was performed, and ensuing histopathological evaluation of the tumors confirmed the diagnosis of cutaneous leiomyomas. Unfortunately, the patient did not appear for the scheduled follow-up visit.

\section{DISCUSSION}

Cutaneous leiomyomas are benign, smooth muscle tumors that may denote an underlying systemic disease. The described patient had been referred to our department for treatment of keloid, which is an abnormal proliferation of scar tissue. It usually forms at the site of cutaneous injury, but many patients cannot recall even minor trauma. In our case the lesions were situated on the shoulder, which is a typical location of keloid. Moreover, the patient was of Asian descent and presented with skin phototype 4/5. Studies have demonstrated that individuals with darker pigmentation and Asian descent are more likely to develop keloids [6]. We believe that these factors contributed to the wrong initial diagnosis established by the general practitioner.

Although the diagnosis of keloid was possible, we decided to perform a skin biopsy in order to confirm or exclude it. The histopathology and immunohistochemistry supported the diagnosis of cutaneous leiomyoma. This is an example of the importance for a dermatologist to perform a comprehensive evaluation of each patient presenting with various cutaneous lesions.

The recognition of cutaneous leiomyoma is clinically relevant, as it is a prominent marker of hereditary leiomyomatosis and renal cell carcinoma (RCC) [2]. Multiple cutaneous and uterine leiomyomatosis syndrome (MCUL) has been previously described as Reed's syndrome [7]. Germline mutations in the fumarate hydratase gene located on the first chromosome (1q42.3-q43) are responsible for the development of this syndrome $[8,9]$. Multiple cutaneous and uterine leiomyomatosis syndrome associated with RCC is known as hereditary leiomyomatosis and renal cell cancer (HLRCC). Early diagnosis and treatment of RCC may contribute to the survival of the affected patient. Appropriate investigations for uterine and renal diseases are warranted in cases of multiple, biopsy-proven cutaneous lesions. In particular cases, genetic counseling might be recommended for other members of the patient's family. Fortunately, screening for uterine leiomyoma and RCC was negative in our patient.

\section{CONCLUSIONS}

Cutaneous leiomyoma is of clinical importance, especially taking into consideration that this condi-

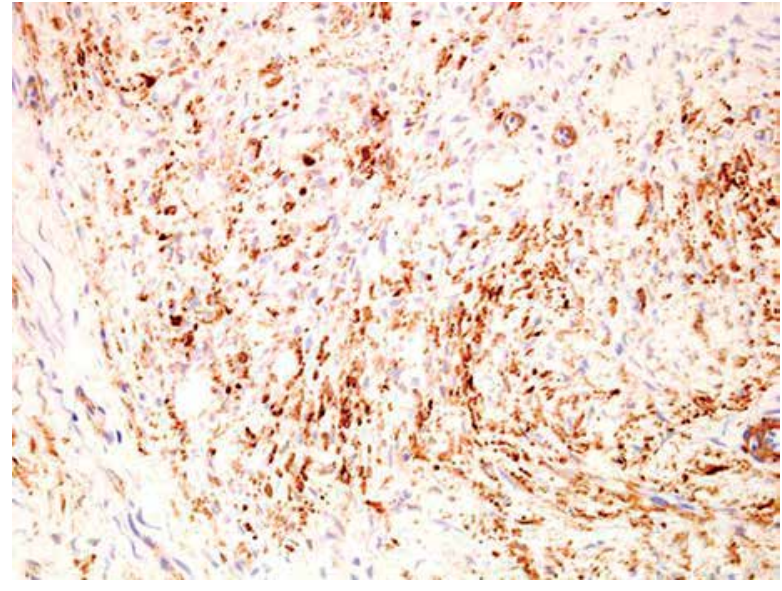

Figure 4. Immunohistochemical staining for smooth muscle actin is positive $(20 \times$ magnification)

Rycina 4. Barwienie immunohistochemiczne uwidaczniające obecność aktyny mięśni gładkich (powiększenie 20×)

tion could be a marker of RCC. Therefore, proper diagnosis and early recognition might be life-saving.

\section{Conflict of interest}

The authors declare no conflict of interest.

\section{References}

1. Virchow R.: Uber Amkroglossie und pathologische Neubildung quergestreifter Muskelfasern. Virchows Arch Pathol Anat 1854, 7, 126-138.

2. Stewart L., Glenn G., Toro J.R.: Cutaneous leiomyomas: a clinical marker of risk for hereditary leiomyomatosis and renal cell cancer. Dermatol Nursing 2006, 18, 335-341.

3. Fisher W.C., Helwig E.B.: Leiomyomas of the skin. Arch Dermatol 1963, 88, 510-520.

4. Wolfram D., Tzankov A., Pülzl P., Piza-Katzer H.: Hypertrophic scars and keloids - a review of their pathophysiology, risk factors, and therapeutic management. Dermatol Surg 2009, 35, 171-181.

5. Atiyeh B.S., Costagliola M., Hayek S.N.: Keloid or hypertrophic scar: the controversy: review of the literature. Ann Plast Surg 2005, 54, 676-680.

6. Alhady S.M., Sivanantharajah K.: Keloids in various races. A review of 175 cases. Plast Reconstr Surg 1969, 44, 564-566.

7. Badeloe S., Frank J.: Clinical and molecular genetic aspects of hereditary multiple cutaneous leiomyomatosis. Eur J Dermatol 2009, 19, 545-551.

8. Alam N.A., Bevan S., Churchman M., Barclay E., Barker K., Jaeger E.E., et al.: Localization of a gene (MCUL1) for multiple cutaneous leiomyomata and uterine fibroids to chromosome 1q42.3-q43. Am J Hum Genet 2001, 68, 1264-1269.

9. Tomlinson I.P., Alam N.A., Rowan A.J., Barclay E., Jaeger E.E., Kelsell D., et al.: Germline mutations in FH predispose to dominantly inherited uterine fibroids, skin leiomyomata and papillary renal cell cancer. Nat Genet 2002, $30,406-410$.

Submitted: 27 VI 2016

Accepted: 2 VIII 2016 